\title{
Nurses' perception of privacy protection in haemodialysis
}

\author{
Preservação da privacidade em hemodiálise: perceção dos enfermeiros \\ Preservación de la privacidad en hemodiálisis: percepción de los enfermeros \\ Cristina Maria Medeiros Guedes Ferreira de Moura*; Maria Manuela Martins**; Alexandrina \\ Lobo $^{* * *}$; Catarina Renata Ribeiro****; Catarina Sequeira****
}

\begin{abstract}
Theoretical framework: In haemodialysis, nurses tend to direct their attention towards the technical procedures, often ignoring the patients' feelings and privacy.

Objectives: To describe nurses' perception of the protection of patients' privacy during haemodialysis and analyse the differences based on sociodemographic variables and length of service.

Methodology: A quantitative descriptive exploratory study was conducted with a sample of 452 nurses. The Escala de preservação da privacidade do cuidar em hemodiálise (Scale of privacy protection during haemodialysis) validated by the authors was used.

Results: The results show that nurses believe that the protection of privacy during haemodialysis is very important. Female nurses highlighted the communication component, assigning higher importance to privacy protection care. The higher the number of years of experience, the higher the concern over privacy protection.

Conclusion: The nurses, particularly female nurses, perceive «communication» and «care humanisation» to be priority dimensions in the protection of privacy during haemodialysis.
\end{abstract}

Keywords: privacy; nurse-patient relations; hemodialysis.

\section{Resumo}

Enquadramento: Na hemodiálise os enfermeiros tendem a direcionar a sua atenção para os procedimentos técnicos, ignorando muitas vezes os sentimentos e privacidade das pessoas que vivenciam a sua condição de doente. Objetivos: Descrever a perceção dos enfermeiros sobre a preservação da privacidade do doente durante o tratamento hemodialítico e analisar as diferenças tendo em conta as variáveis sociodemográficas e tempo de serviço. Metodologia: Estudo quantitativo, descritivo/exploratório, com uma amostra de 452 enfermeiros. Foi utilizada a «Escala de preservação da privacidade do cuidar em hemodiálise», validada pela autora.

Resultados: Os resultados evidenciam que os enfermeiros atribuem importância à preservação da privacidade na prestação de cuidados em hemodiálise. O sexo feminino destacou positivamente a comunicação, atribuindo maior importância aos cuidados relacionados com a preservação da privacidade. À medida que aumenta o número de anos de experiência no serviço de hemodiálise, também aumenta a preocupação com a preservação da privacidade.

Conclusão: Os enfermeiros, nomeadamente as mulheres, percecionam a «comunicação» e a "humanização dos cuidados" como dimensões privilegiadas no cuidar da privacidade em hemodiálise.

Palavras-chave: privacidade; relações enfermeiro-paciente; diálise renal.

* MSc., Adjunct Professor, School of Nursing Dr. José Timóteo Montalvão Machado, 5400-673, Chaves, Portugal [cmmgfmoura@hotmail.com]. Address for correspondence: School of Nursing Dr. José Timóteo Montalvão Machado Quinta dos Montalvões, Outeiro Seco, 5400-673, Chaves. Contribution to the article: bibliographic search; data collection and discussion; article writing. ** Ph.D., Coordinating Professor, Porto Nursing College, 4200-072, Porto, Portugal [mmartins@ esenf.pt]. Contribution to the article: article writing and revision.

*** Ph D Coordinating Professor School of Nursing Dr José Timóteo Montalyão Machado, 5400 673, Ch. Doses and evaluation, and data analysis. Address for correspondence: Av. Padre Júlio Fragata no $109,3.1$, 4710-413, Braga, Portugal.

**** MSc., Assistant Professor, School of Nursing Dr. José Timóteo Montalvão Machado, 5400-673, Chaves, Portugal [cribeiro@esechaves.pt]. Contribution to the article: bibliographic search and data collection.

***** RN, Assistant Professor, School of Nursing Dr. José Timóteo Montalvão Machado, 5400-673, Chaves, Portugal. Contribution to the article: article writing.

\section{Resumen}

Marco contextual: En la hemodiálisis los enfermeros tienden a prestar gran parte de su atención a los procedimientos técnicos e ignoran, a menudo, los sentimientos y la privacidad de las personas que sufren una enfermedad.

Objetivos: Describir la percepción de los enfermeros sobre la preservación de la privacidad del paciente durante la hemodiálisis y analizar las diferencias en cuanto a las variables sociodemográficas y el tiempo de servicio.

Metodología: Estudio cuantitativo, descriptivo/exploratorio, con una muestra de 452 enfermeros, para el cual se utilizó la «Escala de preservación de la privacidad de la atención en hemodiálisis», validada por la autora.

Resultados: Los resultados muestran que los enfermeros dan importancia a la preservación de la privacidad en la prestación de cuidados en hemodiálisis. El sexo femenino destacó positivamente la comunicación y dio mayor importancia a los cuidados relacionados con la preservación de la privacidad. A medida que aumenta el número de años de experiencia en el servicio de hemodiálisis, también aumenta la preocupación por la preservación de la privacidad.

Conclusión: Los enfermeros, sobre todo las mujeres, perciben la «comunicación» y la «humanización de los cuidados» como dimensiones privilegiadas de la atención a la privacidad en hemodiálisis.

Palabras clave: privacidad; relaciones enfermero-paciente; diálisis renal.

Received for publication: 14.07 .14

Accepted for publication: 17.03.15 


\section{Introduction}

Evidence shows that nurses are inevitably in a position to influence privacy protection, which should be an essential part of their professional conduct. This fact supports the importance of intervening to protect privacy, which is an ethical value in the haemodialysis units that relies on the nurses' effort and dedication during care provision (Soares \& Dall' Agnol, 2011).

Recent studies have underlined that care provision in haemodialysis units is primarily directed towards physical, organic, and biological aspects, such as the control and maintenance of vital functions, with emphasis on the use of technologies and application of technical-scientific knowledge to maintain life. Although the Nursing team directs their attention towards the patient and the haemodialysis treatment, being almost exclusively responsible for all technical procedures, the team often ignores the patients' human and relational side, especially their privacy (Baggio, Pomatti, Bettinelli, \& Erdmann, 2011; Frazão, Ramos, \& Lira, 2011; Moura, 2006).

Therefore, a study was conducted to describe the nurses' perception of the protection of patients' privacy during haemodialysis and analyse the differences taking into account the sociodemographic variables and the length of service.

\section{Background}

The concern with the users' privacy has been an object of study, discussion, and reflection throughout the course of history. Historical accounts indicate that Hippocrates was one of the pioneers in the formulation of principles and laws aimed at the protection of users' privacy rights by the health professionals. The ethics of Hippocrates stands out in the Hippocratic Oath, which is considered to be at the basis of the ethics of health professionals (Soares \& Dall' Agnol, 2011).

Taking into account that privacy, as a universal right, is legally considered as an intangible property protected by law, its invasion represents a type of semi-intentional offense that implies the violation of the person's right to privacy (Martins, 2009).

As an individual right, privacy includes the protection of intimacy, the respect for dignity, and the limitation of access to the body, intimate objects, and family and social relationships.
Although private life or privacy is recognised in articles 26 and 64 of the Constitution of the Portuguese Republic, the Code of Conduct, the Universal Declaration of Human Rights and the Carta dos Direitos dos Doentes Internados (Charter of the Rights of Inpatients), it is easily attacked by a diversity of scourges.

According to the International Council of Nurses, respecting human rights and maintaining dignity are defined as ethical goals of the nurse/patient relationship, which should not differ due to the patient's race, age, religion, sickness or handicap, gender, or political, social and economic status (Lin \& Tsai, 2010).

The scientific evidence on healthcare settings has been the object of study of various authors who are concerned about the ethical dimension of care, the possibility of violation of the patients' intimacy, as well as the violation of secrets and confidences obtained in the nurse/patient relationship (Baggio et al., 2011; Maia \& Silva, 2009; Soares \& Dall' Agnol, 2011).

Patients have their own lifestyles, assigning a very specific meaning to their own privacy. Hence the nurses need to understand the patient as a whole. In many ways, the nurses are professionals who have the privilege to be in closer contact with the patients, having a major responsibility in protecting their privacy during care.

Despite the professionals' commitment to soften this care, it is sometimes a difficult task to accomplish in this environment, demanding attitudes of respect for the patients' privacy, individuality, and dignity (Ribeiro, 2008).

Thus, caring is respecting the others' privacy, by not invading their intimate territory and accepting their shyness. Understanding, acceptance, encouragement, affection, and respect should be present in all procedures. Caring for someone involves respecting each person's individuality, which, together with humanisation and communication as moral ideas of nurses (Morais, 2009), should aim at protecting, improving, and preserving human dignity (Watson, 2002).

Quality care is undoubtedly integral, universal, equitable, and humanised. Studies conducted by nurses recurrently define humanism as solidarity action and mutual aid, i.e., using our humanity to care for the humanity of the other (Corbani, Bretas, \& Matheus, 2009). 
The concept of humanisation is widely represented in the health area and focuses, among other aspects, on the ethical dimensions of care and the importance of communication in the therapeutic process committed to the patients' life and rights (Deslandes \& Mitre, 2009). According to the same author, among these significant challenges, communication should be highlighted as a much broader process of what we are as human beings, as social beings of language, able to denote/connote, explain/confuse, allow/disallow, and consent/forbid.

When we talk about communication in haemodialysis units, we refer to the expansion of a communication skill that is at the basis of an empowering care and management, in which the different players recognise and engage one another.

In addition, the time patients spend at haemodialysis units for a 4-hour treatment three to four times a week promotes a closer communication process due to the situation of chronic disease.

Thus, communication becomes one of the central axes, which must be considered not only as a humanising action, but also as a decisive factor for the provision of quality nursing care at haemodialysis units (Londoño, 2009).

\section{Research questions}

What is the nurses' perception of patient privacy protection during the haemodialysis treatment?

What is the influence of the sociodemographic variables and length of service in privacy protection?

\section{Methodology}

A quantitative, descriptive and exploratory study was conducted to answer the research questions.

This study focused on a population composed of approximately 1200 nurses working in the private haemodialysis clinics in Portugal. The sample was comprised of 452 nurses. The following inclusion criteria were applied: being a healthcare professional (nurse) working in haemodialysis units and accepting to participate in the study.

A non-probability, purposive sample was used to homogenise Nursing care, taking into account the patient's privacy.

Data were collected through the Escala de preservação da privacidade do cuidar em bemodiálise (EPPCH) (Scale of privacy protection during haemodialysis), validated by the authors, which consists of three parts. The first part covers the respondents' socio-professional characteristics: gender, marital status, years of service in nursing, years of experience in the current service, and professional category. The second part comprises two 24-item subscales: the first subscale aims to assess the level of importance assigned by respondents to the protection of patients' privacy during care provision in haemodialysis through a 7-point Likert scale, in which 1 corresponds to the "least important» and 7 corresponds to the «most important»; the second subscale (EFPPCH) assesses the extent to which the items are implemented by the respondents with a view to maintaining the patients' privacy during care provision in haemodialysis, by means of a 5-point Likert scale, in which 1 corresponds to «never» and 5 corresponds to «always». In each of the subscales, the following dimensions are considered: (i) physical space $(\alpha=0.762)$; (ii) body exposure ( $\alpha=0.807)$; (iii) care humanisation ( $\alpha=0.765)$; (iv) communication $(\alpha=0.814)$; and (v) sociodemographic characterisation (gender; age; marital status; academic qualifications; profession; and length of service).

Data were collected between March and April 2013.

Before data collection, authorisation was requested to the boards of directors of the private haemodialysis clinics, and the nurses' informed consent was obtained.

Data were analysed using the Statistical Package for the Social Sciences (SPSS), version 17.0 for Windows. Descriptive statistics (measures of central tendency and dispersion) and percentage analysis were used to highlight and systematise the information in the data. In the inferential analysis, the student's t-test and Pearson's correlation coefficient were used to compare the results according to gender and analyse the inter-item relationship, respectively (Marôco, 2010).

\section{Results}

A total of 452 nurses participated in the study, with a mean age of 36.2 years \pm 9.3 years (minimum $=22$; maximum $=61)$, of whom $64.8 \%(n=293)$ were female. The median shows that at least $51.1 \%$ 
$(\mathrm{n}=231)$ of the sampled nurses is under 34 years of age and that the most frequent age is 27 years. Most respondents are married or living together (57.5\%; $\mathrm{n}=260)$ and $33.8 \%(\mathrm{n}=153)$ are single.

It was observed that the protection of patients' privacy during care provision in haemodialysis is overall considered to be very important, given that the mean of all items is higher than 6. Communication between the healthcare professional and the patient is the most valued dimension $(\mathrm{m}=6.6 ; \mathrm{sd}=0.5)$ and

Table 1

Subscale of Importance of Privacy Protection by Gender

\begin{tabular}{lllllll}
\hline \hline & & \multirow{2}{*}{$\mathrm{n}$} & Mean & $\mathrm{sd}$ & \multicolumn{2}{c}{ T-test } \\
\cline { 6 - 8 } Physical Space & Gender & & & & $t$ & $\mathrm{p}$ \\
& Female & 293 & 6.3 & .6 & .448 & .654 \\
& Male & 159 & 6.2 & .6 & & \\
\hline \multirow{2}{*}{ Body Exposure } & Female & 293 & 6.2 & .6 & .191 & .848 \\
& Male & 159 & 6.2 & .7 & & \\
\hline \multirow{2}{*}{ Care Humanisation } & Female & 293 & 6.4 & .6 & $\mathbf{2 . 3 4 2}$ & .020 \\
& Male & 159 & 6.2 & .6 & & \\
\hline \multirow{2}{*}{ Communication } & Female & 293 & 6.7 & .4 & $\mathbf{3 . 4 3 6}$ & .001 \\
& Male & 159 & 6.5 & .6 & & \\
\hline \multirow{2}{*}{ Total Importance } & Female & 293 & 6.4 & .5 & $\mathbf{2 . 1 9 4}$ & .045 \\
& Male & 159 & 6.3 & .5 & & \\
\hline \hline
\end{tabular}

As regards the comparison of the subscale of higher in the dimension 'communication' $(t=2.477$; frequency of patient privacy protection (Table 2), $p=0.014$ ).

it was observed that women scored significantly

Table 2

Subscale of Frequency of Privacy Protection by Gender

\begin{tabular}{|c|c|c|c|c|c|c|}
\hline & \multirow[b]{2}{*}{ Gender } & \multirow{2}{*}{$\mathrm{n}$} & \multirow{2}{*}{ Mean } & \multirow{2}{*}{ sd } & \multicolumn{2}{|c|}{$\bar{T}$ T-test } \\
\hline & & & & & $t$ & $p$ \\
\hline \multirow{2}{*}{ Physical Space } & Female & 293 & 3.5 & .6 & -.984 & .326 \\
\hline & Male & 159 & 3.5 & .6 & & \\
\hline \multirow{2}{*}{ Body Exposure } & Female & 293 & 3.6 & .5 & -.562 & .574 \\
\hline & Male & 159 & 3.7 & .5 & & \\
\hline \multirow{2}{*}{ Care Humanisation } & Female & 293 & 3.4 & .5 & -.744 & .458 \\
\hline & Male & 159 & 3.5 & .6 & & \\
\hline \multirow{2}{*}{ Communication } & Female & 293 & 4.4 & .4 & 2.477 & .014 \\
\hline & Male & 159 & 4.3 & .5 & & \\
\hline \multirow{2}{*}{ Total Frequency } & Female & 293 & 3.8 & .4 & -.216 & .829 \\
\hline & Male & 159 & 3.8 & .4 & & \\
\hline
\end{tabular}


Table 3 shows Pearson's correlation regarding the importance of privacy protection. It can be concluded that years of service and experience in haemodialysis have no significant relationship with the dimensions under study. On the other hand, the participants' age is negatively and significantly associated with care humanisation and communication $(r=-0.289$; $p=0.019$ and $r=-0.269 ; p=0.025$ ).

Table 3

Correlation between the Subscale of Importance of Privacy Protection and Age and Length of Service

\begin{tabular}{|c|c|c|c|c|}
\hline & & Age & $\begin{array}{l}\text { Years Nursing } \\
\text { Service }\end{array}$ & $\begin{array}{c}\text { Years Haemodialysis } \\
\text { Experience }\end{array}$ \\
\hline \multirow{2}{*}{ Physical Space } & $r$ & -.012 & .025 & .033 \\
\hline & $p$ & .800 & .601 & .481 \\
\hline \multirow{2}{*}{ Body Exposure } & $r$ & -.020 & .023 & .029 \\
\hline & $p$ & .672 & .624 & .542 \\
\hline \multirow{2}{*}{ Care Humanisation } & $r$ & $-.289^{*}$ & -.062 & -.049 \\
\hline & $p$ & .019 & .191 & .302 \\
\hline \multirow{2}{*}{ Communication } & $r$ & $-.269^{*}$ & -.082 & -.059 \\
\hline & $p$ & .025 & .083 & .208 \\
\hline \multirow{2}{*}{ Total Importance } & $r$ & -.061 & -.019 & -.006 \\
\hline & $\underline{p}$ & 198 & 681 & .897 \\
\hline
\end{tabular}

*. The correlation is significant at .05

As regards the association between these variables and the frequency of patient privacy protection (Table 4), their total score is positively associated with age

Table 4

Correlation between the Subscale of Frequency of Privacy Protection and Age and Length of Service

\begin{tabular}{|c|c|c|c|c|}
\hline & & Age & $\begin{array}{l}\text { Years Nursing } \\
\text { Service }\end{array}$ & $\begin{array}{c}\text { Years Haemodialysis } \\
\text { Experience }\end{array}$ \\
\hline \multirow{2}{*}{ Physical Space } & $r$ & .040 & .022 & .037 \\
\hline & $p$ & .401 & .640 & .438 \\
\hline \multirow{2}{*}{ Body Exposure } & $r$ & .092 & $.251^{*}$ & $.356^{\star *}$ \\
\hline & $p$ & .052 & .026 & .007 \\
\hline \multirow[t]{2}{*}{ Care Humanisation } & $r$ & .076 & .073 & .089 \\
\hline & $p$ & .105 & .120 & .059 \\
\hline \multirow{2}{*}{ Communication } & $r$ & .007 & .017 & .018 \\
\hline & $p$ & .882 & .717 & .695 \\
\hline \multirow{2}{*}{ Total Frequence } & $r$ & $.209^{\star}$ & .084 & $.199^{\star}$ \\
\hline & $p$ & .044 & .074 & .035 \\
\hline
\end{tabular}

**. The correlation is significant at .01

*. The correlation is significant at .05

The years of service in the profession correlates significantly with the dimension 'body exposure' $(r=0.251 ; p=0.026)$. In addition, the years of experience in the dialysis service is associated with the dimension body exposure $(\mathrm{r}=0.356 ; p=0.007)$ and $(\mathrm{r}=0.209 ; p=0.044)$, indicating that the older the nurses, the higher the frequency of privacy protection. 


\section{Discussion}

The study on the perception of privacy protection during care provision in haemodialysis shows that women often value communication, assigning more importance to humanisation, which seems to be related with the historical legacy assigned to women as promoters of caring (Queirós, 2005). Women have always taken care of all aspects of daily life - womanmother, woman-religious sister, woman-nurse ensuring care that maintains the vital functions, but also in other domains of the individual as a person.

Humanisation should be perceived as an end in itself, as the means par excellence to achieve quality care (Corbani et al., 2009). According to the same author, this corresponds to the human essence, endowing it with dignity and providing it with an ontological view. The existence of a close link between privacy promotion and assertive communication should also be highlighted since communication is both a vehicle for the establishment of a therapeutic relationship and a means to influence the behaviour of the other (Ruiz, Martins, \& Borrego, 2014). Thus, to promote privacy during care provision, it is of great importance to also promote an effective communication as a basic instrument in the Nursing care process (Morais, 2009).

The older the nurses, the less importance they assign to these dimensions, which seems to be associated with the relativisation of care, or even to the nonoptimisation of accumulated experience (Benner, 2005; Queirós, 2005). In addition, the higher the length of service, the higher the frequency of patient privacy protection, particularly in terms of body exposure $(\mathrm{r}=0.251 ; p=0.026)$.

Given the growing demand of the current socioeconomic context, healthcare professionals tend to focus on technicality and efficiency to develop successful interventions (Delbrouck, 2006). Since people are always the component that makes the difference, an investment should be made in personalised care, honouring the professional ethics that values dignity and taking into account the patients' rights and duties recognised in the legislation in force (including articles 26 and 64 of the Constitution of the Portuguese Republic and the National Health Plan). In addition to the concern of various organisations and bodies with care humanisation, a greater strategic mobilisation of individual actions with an impact on policies is needed. One of the limitations of this study was the fact that data reported nurses' perception, thus this phenomenon should be further explored so that it can contribute more significantly to the discipline of Nursing. It should also be mentioned that the use of a non-probability, purposive sample limits generalizability, although the dispersion of participants justifies this method. Finally, another limitation is that these perspectives are related to a specific Nursing area which is subject to internal and external social influences given the current situation.

\section{Conclusion}

The results show that all variables are significantly interrelated and positively associated. In general, women assign greater importance to care humanisation and communication, often valuing this latter dimension. The older the nurses, the less importance they assign to these dimensions. However, the older they are, the higher is the frequency of privacy protection.

The increase in the number of years of service and experience in the dialysis service is associated with increased frequency of patient privacy protection, particularly in terms of body exposure.

After recognition of the importance of assessing privacy protection during haemodialysis as an indicator of excellence in health care, the dissemination of these results will contribute to changing attitudes and, consequently, improving the skills of haemodialysis nurses.

\section{References}

Baggio, M. A., Pomatti, D. M., Bettinelli, L. A., \& Erdmann, A. L. (2011). Privacidade em unidades de terapia intensiva: Direitos do paciente e implicações para a enfermagem. Revista Brasileira Enfermagem, 64(1), 25-30.

Benner, P. (2005). De iniciado a perito (2a ed.). Coimbra, Portugal: Quarteto.

Corbani, N. M. S., Brêtas, A. C. P., \& Matheus, M. C. C. (2009). Humanização do cuidado de enfermagem: O que é isso?. Revista Brasileira Enfermagem, 62(3), 349-354.

Deslandes, S. F., \& Mitre, R. M. A. (2009). Processo comunicativo e humanização em saúde. Interface Comunicação Saúde Educação, 13(Sup.1), 641-649. 
Delbrouck, M. (2006). Síndromes associadas ou conexas com a exaustão: Sindrome de exaustão (burnout). Lisboa, Portugal: Climepsi.

Frazão, C., Ramos, V. \& Lira, A. (2011). Qualidade de vida de pacientes submetidos a hemodiálise. Rev. Enferm. UERJ, 19 (4), $577-582$.

Lin, Y.-P., \& Tsai, Y.-F. (2010). Maintaining patients' dignity during clinical care: A qualitative interview study. Journal of Advanced Nursing, 67 (2), 340-348. doi:10.1111/j.13652648.2010.05498.x

Londoño, E. G. (2009). El cuidado de enfermería del paciente en estado crítico: Una perspectiva bioética. Persona Y Bioética, 2(31), 145-157.

Maia, R.F. \& Silva, R.C. (2009). A privacidade do cliente em terapia intensiva e as implicações para a prática de enfermagem. Journal of Nursing UFPE on line, 3(4), 365373. doi: $10.5205 / 01012007$.

Martins, A. R. (2009). A privacidade do doente internado. Enfermagem Oncológica, 12(1), 29-31.

Marôco, J. (2010). Análise de equações estruturais: Fundamentos teóricos, software \& aplicações. Pêro Pinheiro, Portugal: ReportNumber.

Morais, G. S. N. (2009). Comunicação como instrumento básico no cuidar humanizado em enfermagem ao paciente hospitalizado. Acta Paulista de Enfermagem, 22(03), 323327.

Moura, C. (2006). Cuidados de enfermagem à pessoa com insuficiência renal crónica terminal: Da percepção do utente à concepção dos enfermeiros. Dissertação de mestrado não publicada, Universidade do Porto, Instituto de Ciências Biomédicas Abel Salazar, Porto.

Queirós, P. J. P. (2005). Burnout no trabalho e conjugal nos enfermeiros e o clima organizacional. Revista Investigação em Enfermagem, 11, 1-15.

Ribeiro, L. M. (2008). Humanização do espaço arquitetônico em unidade de hemodiálise (Monografia apresentada ao Curso de Especialização em Arquitetura). Faculdade de Arquitetura, Universidade Federal da Bahia, Brasil.

Ruiz, M., Martins, M. M., \& Borrego, M. A. (2014). Tecnología y comunicación en el cuidado hospitalario a enfermos crónicos desde la perspectiva de Habermas. Texto Contexto Enfermagem, 23(3), 704-11.

Soares, N. V., \& Dall'Agnol, C. M. (2011). Privacidade dos pacientes: Uma questão ética para a gerência do cuidado em enfermagem. Acta Paulista Enfermagem, 24(5), 683-688.

Watson, J. (2002). Enfermagem pós-moderna e futura um novo paradigma da enfermagem. Loures, Portugal: Lusociência. 
